Original article

\title{
A cross sectional study assessing the knowledge and attitudes towards lumbar puncture among the staff of a public university in Malaysia
}

\author{
Wan Aliaa Wan Sulaiman ${ }^{\mathrm{a}, \mathrm{d}, *}$, Suhainizam Muhamad Saliluddin ${ }^{\mathrm{b}}$, Yun Jin Ong ${ }^{\mathrm{b}}$, \\ Sazlyna Mohd Sazlly Lim ${ }^{a}$, Liyana Najwa Inche Mat ${ }^{\mathrm{a}, \mathrm{d}}$, Fan Kee Hoo ${ }^{\mathrm{a}, \mathrm{d}}$, \\ Ramachandran Vasudevan ${ }^{\mathrm{d}}$, Siew Mooi Ching ${ }^{\mathrm{d}, \mathrm{e}}$, Hamidon Basri ${ }^{\mathrm{a}}$, \\ Mohd Hazmi Mohamed ${ }^{\mathrm{C}}$ \\ a Department of Medicine, Faculty of Medicine and Health Sciences, University Putra Malaysia, Serdang, Malaysia \\ b Department of Community Health, Faculty of Medicine and Health Sciences, University Putra Malaysia, Serdang, Malaysia \\ ${ }^{\mathrm{c}}$ Department of Surgery, Faculty of Medicine and Health Sciences, University Putra Malaysia, Serdang, Malaysia \\ d Institute of Gerontology, Universiti Putra Malaysia, 43400, Serdang, Selangor, Malaysia \\ e Department of Family Medicine, Faculty of Medicine and Health Sciences, University Putra Malaysia, Serdang, Malaysia
}

\section{A R T I C L E IN F O}

Article history:

Received 15 March 2017

Accepted 24 May 2017

Available online 30 May 2017

\section{Keywords:}

Lumbar puncture

Cerebrospinal fluid

Central nervous system

Knowledge

Attitude

\begin{abstract}
A B S T R A C T
Problem considered: Lumbar puncture (LP) refusal rates of as high as $30 \%$ have been reported in developing countries. Without LP, the patients may suffer suboptimal treatment or unnecessary complications from their disease. Due to a lack of studies exploring the reasons behind this LP refusal, no solution has been suggested to address this problem. Therefore, we carried out this study with the aim of determining knowledge of and attitude towards LP among the public.

Methods: A cross-sectional survey study among staff in a public university in Malaysia was conducted using stratified random sampling. Self-administered questionnaires were sent to 500 staff members from April to August 2015. The questionnaire, which included questions on demography, knowledge and attitude towards LP, was pre-tested and validated (Cronbach's alpha $=0.701$ ).

Results: A total of 316 of 500 (63\%) responded, of which 294 were complete and analysed. The median (IQR) age was 34 and 65\% were female. 80\% had tertiary education. The mean knowledge score was $6 \pm 3$; $74 \%$ were categorised into poorly informed, $23 \%$ moderately informed, and 3\% well-informed. The mean attitude score was $35 \pm 4$; $3 \%$ were categorised as having poor attitude, $72 \%$ moderate attitude, and $27 \%$ good attitude. Respondents with higher education had a higher knowledge and attitude $s c o r e(p=0.001)$, while respondents afraid of needles had a lower attitude score $(p=0.019)$. Total knowledge scores and total attitude scores showed a positive correlation $(r=0.272, p=0.001)$.

Conclusion: The public are not adequately informed about LP, leading to the unreceptive attitudes towards LP consent. Therefore, the public should be educated about LP to create better awareness.
\end{abstract}

(c) 2017 INDIACLEN. Published by Elsevier, a division of RELX India, Pvt. Ltd. All rights reserved.

\section{Introduction}

Lumbar puncture (LP), also known as spinal tap, is a routine procedure to obtain cerebrospinal fluid (CSF) for either diagnostic or therapeutic indications for neurological diseases. Even though LP is important, from our clinical experience we found that some patients refuse consent.1,2 Likewise, some parents are reluctant to give consent for LP to be done on their children.3,4 One study

\footnotetext{
* Corresponding author at: Department of Medicine, Faculty of Medicine and Health Sciences, University Putra Malaysia, Serdang, Malaysia.

E-mail addresses: wanaliaa@upm.edu.my, drwanaliaa@gmail.com (W.A. Wan Sulaiman).
}

identified that fear of complications and the conviction that LP is unnecessary are the main reasons behind LP refusal.5 Without LP, patients may have to undergo unnecessary empirical treatment such as intravenous antivirals or broad spectrum antibiotics which increase the risk of antibiotic resistance. This may lead to prolonged hospital stays, increased hospitalisation costs, and added burdens on the health service.

LP refusal has been reported in some developing regions such as Malaysia,3,6 Africa,7,8 Iran9 and Saudi Arabia.5 The refusal rate of LP is about $30 \%$ as shown by two studies.3,6 Due to the lack of studies exploring the reasons behind this LP refusal, no solution could be suggested to address this problem. Therefore, we carried out this study with the aim of identifying the public knowledge of 
and attitude towards LP. We also aimed to identify differences in knowledge and attitude of LP and the associations among respondents. The results will help develop suitable interventions to resolve the problems of LP refusal and thus improve acceptance of LP among the public.

\section{Methodology}

We carried out a cross-sectional study among Malaysian staff in a public university in Malaysia using stratified random sampling. The sampling units included 13 faculties after exclusion of medical and veterinary faculty. Respondents from each faculty were then chosen by simple random sampling by using SPSS. Based on approximately 2540 staff members from the included faculties and adjusted for an $80 \%$ response rate, the minimum calculated sample size required was 291 (CI 1.96). Self-administered questionnaires were sent to 500 staff members from April to August 2015. Respondents gave consent in writing to participate in this study and all data collected were kept confidential. Ethical approval for the study was obtained from the Institutional Review Board of the University of Putra Malaysia.

The questionnaire, adapted from two previous study,7,9 was translated to Bahasa Malaysia and pre-tested and validated on 38 non-medical staff (Cronbach's alpha $=0.701$ ). It included measures to assess baseline demographic and socioeconomic data, knowledge and attitude towards LP. The socio-demographic questions comprised of age, gender, ethnicity, education level and monthly income groups. Questions on previous experience, awareness of LP, and fear of needles were also included. The knowledge section consisted of 18 questions mainly concerning the nature of the procedure, indication and complication of LP. One score was given for each correct response. Respondents with a knowledge score $<50 \%$ were considered as poorly-informed, with $50-75 \%$ moderately-informed and $>75 \%$ well-informed. The attitude section consisted of 10 questions with Likert scale, whereby 1 to 5 scores were given for each question. An attitude score of $<50 \%$ was considered poor, $50-75 \%$ was moderate, and $>75 \%$ was good.

The data was analysed using SPSS Version 21.0. A chi-square test was used to assess the significance of association between socio demographic characteristics and levels of knowledge and attitudes towards LP. The alpha level of significance was set at a value of 0.05 . Incomplete questionnaires with missing responses to the knowledge and attitude questions were excluded. For those with missing demographic data, the denominator was used based on the available responses.

Table 1

Socio-demographic characteristics of respondents.

\begin{tabular}{llll}
\hline Socio-demographic characteristics & $\mathrm{N}$ & $(\%)$ \\
\hline Age (years) & $20-29$ & 66 & 22.4 \\
& $30-39$ & 126 & 42.9 \\
& $40-49$ & 54 & 18.4 \\
& $50-59$ & 40 & 13.6 \\
Gender & $60-69$ & 5 & 1.7 \\
& Male & 102 & 34.7 \\
Ethnicity & Female & 192 & 65.3 \\
& Malay & 264 & 89.8 \\
\multirow{3}{*}{ Occupation } & Chinese & 24 & 8.2 \\
& Indian & 6 & 2.0 \\
\multirow{2}{*}{ Education level } & Academic staff & 96 & 32.7 \\
& Administrative staff & 70 & 23.8 \\
& Supporting staff & 128 & 43.5 \\
& Secondary & 58 & 20 \\
& Tertiary & 236 & 80 \\
\hline
\end{tabular}

\section{Results}

Out of 500 questionnaires distributed, a total of 316 (63\%) received a response, of which 294 were complete and analysed. Table 1 shows the socio-demographics of the respondents. The median (IQR) age of the respondents was 34 (range 30-41) and 65\% were female. A majority were Malays at $90 \%$, and about $80 \%$ of the respondents had tertiary education.

The questionnaires showed that about $82 \%$ of respondents were aware about LP, but none had experienced LP themselves. While four respondents had a previous medical history that required them to consent for LP, none of them consented.

From the 18 knowledge questions, the mean score was $6 \pm 3.74 \%$ were categorised into poorly informed, $23 \%$ were moderately informed, and $3 \%$ were well informed. Table 2 shows the frequency of responses regarding knowledge of LP. For the attitude questions, the mean score was $35 \pm 4$, of which $3 \%$ were categorised with poor attitude, $72 \%$ with moderate attitude, and $27 \%$ with good attitude. Respondents were also asked whether they would consent or not consent should LP be indicated for them. $42 \%$ would agree, $14 \%$ would disagree, and $45 \%$ were undecided. Table 3 shows the frequency of responses regarding attitude towards LP.

Educational levels and occupation of the respondents were significantly associated with both knowledge and attitude score $(\mathrm{p}=0.001)$. Academic staff and respondents with a Master's or $\mathrm{PhD}$ had the highest scores for both knowledge and attitude towards LP $(\mathrm{p}<0.001)$. In addition, respondents with awareness of LP had significantly higher knowledge scores regarding LP $(p=0.001)$. In terms of attitude towards LP, respondents who were afraid of needles had significantly lower scores than those who were not $(p=0.019)$. Table 4 shows the association between the demographics, awareness of LP and fear of needles with the knowledge and attitude of LP.

This study also found a significant positive correlation between total knowledge scores and total attitude scores towards LP $(r=0.272, p=0.001)$. The higher the total knowledge scores, the better the total attitude scores towards LP.

\section{Discussion}

LP is important for diagnostic evaluation of CSF and may also be therapeutic in certain neurological diseases. However, a few studies have reported negative patients attitudes towards LP.3,57,9 A qualitative study in UAE showed that parents who refused LP for their child had fear of complications (75\%), the perception that LP was unnecessary (21\%), and distrust of the motives behind the request for consent. About $50 \%$ were adamant for total refusal of LP. In addition, almost one third were unfamiliar with LP indications.5

Likewise, this study showed that the public were poorly informed about LP and undecided on the procedure. In addition, attitudes towards LP were found to be directly related to level of knowledge. Those with higher knowledge exhibited better attitude towards LP and vice versa, similar to the findings by BorhaniHaghighi et al.9 They found that about $90 \%$ of the respondents had poor knowledge associated with negative attitudes towards LP $(\mathrm{P}<0.0001)$.

This study also revealed that higher educated respondents had better knowledge about LP, a phenomenon which has been demonstrated by studies on stroke and diabetes mellitus.10,11 This shows that educated society are more receptive to health related issues. Cutler et al. postulated in an economic study that individuals with higher education have different thinking process and decision-making patterns.12 In addition, they found that spending on health education is a worthwhile investment which would significantly improve population health.13 
Table 2

Frequency distribution of responses regarding knowledge of lumbar puncture (LP) $(n=294)$.

\begin{tabular}{|c|c|c|c|c|c|c|}
\hline No & Knowledge questions & $\begin{array}{l}\text { I don't know } \\
\mathrm{N}(\%)\end{array}$ & $\begin{array}{l}\text { Yes } \\
\mathrm{N}(\%)\end{array}$ & $\begin{array}{l}\text { No } \\
\mathrm{N}(\%)\end{array}$ & $\begin{array}{l}\text { Correct } \\
\text { response } \mathrm{N}(\%)\end{array}$ & $\begin{array}{l}\text { Incorrect } \\
\text { response } \mathrm{N}(\%)\end{array}$ \\
\hline 1. & In your opinion, which photo shows the LP procedure? & $\mathrm{N} / \mathrm{A}$ & $\mathrm{N} / \mathrm{A}$ & $\mathrm{N} / \mathrm{A}$ & $270(91.8)$ & $24(8.2)$ \\
\hline 2. & In your opinion, which part of the spinal cord that the needle inserted? & $\mathrm{N} / \mathrm{A}$ & $\mathrm{N} / \mathrm{A}$ & $\mathrm{N} / \mathrm{A}$ & $204(69.4)$ & $90(30.6)$ \\
\hline 3. & In your opinion, which photo showed the right LP procedure? & $\mathrm{N} / \mathrm{A}$ & $\mathrm{N} / \mathrm{A}$ & $\mathrm{N} / \mathrm{A}$ & $168(57.1)$ & $126(42.9)$ \\
\hline 4. & $\begin{array}{l}\text { LP is a procedure in which needle is inserted into the lower back of spinal column to withdraw } \\
\text { the brain fluid. }\end{array}$ & $99(33.7)$ & $\begin{array}{l}194 \\
(66.0)\end{array}$ & $\begin{array}{l}1 \\
(0.3)\end{array}$ & $194(66.0)$ & $100(34.0)$ \\
\hline 5. & $\begin{array}{l}\text { Doctors will use analgesics and sedatives during LP. This will make this procedure relatively } \\
\text { painless. }\end{array}$ & $120(40.8)$ & $\begin{array}{l}152 \\
(51.7)\end{array}$ & $\begin{array}{l}22 \\
(7.5)\end{array}$ & $152(51.7)$ & $142(48.3)$ \\
\hline 6. & $\begin{array}{l}\text { This procedure will take only approximately } 10 \mathrm{~min} \text { in the ward. The patient does not need to be } \\
\text { in the operation theatre. }\end{array}$ & $197(67.0)$ & $\begin{array}{l}78 \\
(26.5)\end{array}$ & $\begin{array}{l}19 \\
(6.5)\end{array}$ & $78(26.5)$ & $216(73.5)$ \\
\hline 7. & $\begin{array}{l}\text { Doctors do LP to diagnose bacterial, viral and fungal infections of the brains and spinal cords } \\
\text { such as meningitis and encephalitis disease. }\end{array}$ & $115(39.1)$ & $\begin{array}{l}170 \\
(57.2)\end{array}$ & $\begin{array}{l}9 \\
(3.1)\end{array}$ & $170(57.2)$ & $124(42.2)$ \\
\hline 8. & Doctors do LP to give spinal anaesthetic. & $185(62.9)$ & $\begin{array}{l}55 \\
(18.7)\end{array}$ & $\begin{array}{l}54 \\
(18.4)\end{array}$ & $55(18.7)$ & $239(81.3)$ \\
\hline 9. & Doctors do LP as therapeutic method for some diseases such as cancer by giving chemotherapy. & $179(60.9)$ & $\begin{array}{l}78 \\
(26.5)\end{array}$ & $\begin{array}{l}37 \\
(12.6)\end{array}$ & $78(26.5)$ & $216(73.5)$ \\
\hline 10. & LP can cause severe back pain. & $180(61.2)$ & $\begin{array}{l}69 \\
(23.5)\end{array}$ & $\begin{array}{l}44 \\
(15.0)\end{array}$ & $44(15.0)$ & $250(85.0)$ \\
\hline 11. & After LP, the patient may have urinary incontinence. & $249(84.7)$ & $\begin{array}{l}18 \\
(6.1)\end{array}$ & $\begin{array}{l}27 \\
(9.2)\end{array}$ & $267(9.2)$ & $27(90.8)$ \\
\hline 12. & After LP, the patient may have erectile dysfunction. & $229(77.9)$ & $8(2.7)$ & $\begin{array}{l}57 \\
(19.4)\end{array}$ & $57(19.4)$ & $237(80.6)$ \\
\hline 13. & A CT scan will be done before carrying out LP if any contraindication is suspected. & $178(60.5)$ & $\begin{array}{l}106 \\
(36.1)\end{array}$ & $\begin{array}{l}10 \\
(3.4)\end{array}$ & $106(36.1)$ & $188(63.9)$ \\
\hline 14. & Doctors can use CT scan or MRI instead of LP for accurate diagnosis. & $197(67.0)$ & $\begin{array}{l}57 \\
(19.4)\end{array}$ & $\begin{array}{l}40 \\
(13.6)\end{array}$ & $40(13.6)$ & $254(86.4)$ \\
\hline 15. & LP causes severe complications. & $191(65.0)$ & $\begin{array}{l}58 \\
(19.7)\end{array}$ & $\begin{array}{l}45 \\
(15.3)\end{array}$ & $45(15.3)$ & $249(84.7)$ \\
\hline 16. & LP is a low risk procedure and relatively safe. & $172(58.5)$ & $\begin{array}{l}67 \\
(22.8)\end{array}$ & $\begin{array}{l}55 \\
(18.7)\end{array}$ & $67(22.8)$ & $227(77.2)$ \\
\hline 17. & Commonest complication for LP is post puncture headache. & $238(81.0)$ & $\begin{array}{l}48 \\
(16.3)\end{array}$ & $\begin{array}{l}8 \\
(2.7)\end{array}$ & $48(16.3)$ & $246(83.7)$ \\
\hline 18. & Post puncture headache can be prevented by lying flat for $6 \mathrm{~h}$ after the procedure. & $241(82.0)$ & $\begin{array}{l}45 \\
(15.3)\end{array}$ & $\begin{array}{l}8 \\
(2.7)\end{array}$ & $45(15.3)$ & 249 (84.7) \\
\hline
\end{tabular}

N/A not applicable.

Table 3

Frequency distribution of responses regarding attitude towards lumbar puncture (LP) among respondents $(n=294)$.

\begin{tabular}{|c|c|c|c|c|c|c|}
\hline No & Attitude questions & $\begin{array}{l}\text { Strongly agree } \\
\mathrm{N}(\%)\end{array}$ & $\begin{array}{l}\text { Agree } \mathrm{N} \\
(\%)\end{array}$ & $\begin{array}{l}\text { Neutral N } \\
(\%)\end{array}$ & $\begin{array}{l}\text { Disagree } \mathrm{N} \\
(\%)\end{array}$ & $\begin{array}{l}\text { Strongly disagree } \mathrm{N} \\
(\%)\end{array}$ \\
\hline 1. & In your opinion, our society still cannot accept LP completely. & $46(15.6)$ & $\begin{array}{l}152 \\
(51.7)\end{array}$ & $72(24.5)$ & $24(8.2)$ & $0(0)$ \\
\hline 2. & LP is not safe and should be avoided. & $12(4.1)$ & $49(16.7)$ & $162(55.1)$ & $62(21.1)$ & $9(3.1)$ \\
\hline 3. & In your opinion, society doesn't know the importance of LP as diagnostic method. & $48(16.3)$ & $\begin{array}{l}179 \\
(60.9)\end{array}$ & $58(19.7)$ & $6(2.0)$ & $3(1.0)$ \\
\hline 4. & Society doesn't need more education about LP. & $7(2.4)$ & $6(2.0)$ & $36(12.2)$ & $161(54.8)$ & $84(28.6)$ \\
\hline 5. & If a doctor tells me that I need LP, I prefer to be discharge at my own risk. & $7(2.4)$ & $40(13.6)$ & $132(44.9)$ & $101(34.4)$ & $14(4.8)$ \\
\hline 6. & If a doctor tells me that I need LP, I want him or her to explain the procedure. & $156(53.1)$ & $\begin{array}{l}111 \\
(37.8)\end{array}$ & $20(6.8)$ & $1(0.4)$ & $6(2.0)$ \\
\hline 7. & $\begin{array}{l}\text { Informed consent to carry out LP should be obtained from patients or their first-degree } \\
\text { relatives. }\end{array}$ & $146(49.7)$ & $\begin{array}{l}116 \\
(39.5)\end{array}$ & $24(8.4)$ & $2(0.7)$ & $6(2.0)$ \\
\hline 8. & $\begin{array}{l}\text { If a doctor said you should proceed with LP to diagnose your disease, you will agree by } \\
\text { signing the consent letter. }\end{array}$ & $31(10.5)$ & $91(31.0)$ & $132(44.9)$ & $33(11.2)$ & $7(2.4)$ \\
\hline 9. & $\begin{array}{l}\text { I rather undergo other treatment for a long time than diagnosing my disease by carrying } \\
\text { out LP. }\end{array}$ & $10(3.4)$ & $50(17.0)$ & $155(52.7)$ & $68(23.1)$ & $11(3.7)$ \\
\hline 10. & I would refuse to do LP as my elders don't allow me to do so. & $9(3.1)$ & $13(4.4)$ & $116(39.5)$ & $115(39.1)$ & $41(13.9)$ \\
\hline
\end{tabular}

Another significant finding associated with negative attitude towards LP is fear of needles. It is a spectrum ranging from mild to extreme needle fears. 14 The anxiety caused by the fear may lead to avoidance of medical care, resulting in unfavorable health outcomes. Such fear at irrational and extreme level is known as needle phobia. It is a part of a DSM-5 psychiatric disorder termed as blood-injection-injury phobia, 15 which occurs in about 1 in 10 people.16,17 However, individuals with any degree of needle fear may refuse medical procedures, especially if their knowledge is poor. In our questionnaire, we asked about fear of needles either in the hand or back, which both showed significant association with poorer knowledge and attitude towards LP. In light of the potential suboptimal medical management and outcome resulting from needle fear, treating clinicians must be aware of this condition. To reduce the fear of needles, a systematic review had identified exposure-based psychological interventions and applied muscle tension as proven interventions. 18

That most of the respondents did not know the answer to the knowledge questions and remain neutral to the attitude statements shows there is a good opportunity to improve the attitude of public towards LP mainly via education. The majority of the respondents also agreed that society does not know the 
Table 4

The socio-demographic characteristics of the respondents associated with total knowledge scores and total attitude scores towards lumbar puncture (LP).

\begin{tabular}{|c|c|c|c|c|c|}
\hline Variable & $\mathrm{N}$ & $\begin{array}{l}\text { Total knowledge scores of LP } \\
\text { Median (IQR) }\end{array}$ & $p$-value & $\begin{array}{l}\text { Total attitude score of LP } \\
\text { Median (IQR) }\end{array}$ & $p$-value \\
\hline Gender $(n=294)$ & & & 0.056 & & 0.922 \\
\hline Male & 102 & $5.00(5.00)$ & & $35.0(6.0)$ & \\
\hline Female & 192 & $6.00(5.00)$ & & $35.0(5.0)$ & \\
\hline Race $(n=294)$ & & & 0.824 & & 0.422 \\
\hline Malay & 264 & $6.0(5.0)$ & & $35.0(6.0)$ & \\
\hline Chinese & 24 & $5.5(5.0)$ & & $36.0(6.0)$ & \\
\hline Indian & 6 & $7.0(9.0)$ & & $37.5(6.0)$ & \\
\hline Occupation $(n=294)$ & & & $0.007^{*}$ & & $0.003^{*}$ \\
\hline Academic staff & 96 & $7.0(5.0)$ & & $36.5(7.0)$ & \\
\hline Administrative staff & 70 & $5.0(5.0)$ & & $35.0(5.0)$ & \\
\hline Supporting staff & 128 & $6.0(4.0)$ & & $35.0(5.0)$ & \\
\hline Education level $(n=294)$ & & & $0.000^{*}$ & & $0.000^{*}$ \\
\hline Secondary school & 58 & $4.0(4.0)$ & & $34.0(6.0)$ & \\
\hline 1st degree/Diploma & 128 & $6.0(4.0)$ & & $35.0(5.0)$ & \\
\hline Master/PhD & 108 & $7.0(5.0)$ & & $36.0(6.0)$ & \\
\hline Awareness on LP $(\mathrm{N}=294)$ & & & $0.000^{*}$ & & 0.659 \\
\hline No & 54 & $4.5(5.0)$ & & $36.0(6.0)$ & \\
\hline Yes & 240 & $6.0(5.0)$ & & $35.0(5.0)$ & \\
\hline Family or friend' s experience with LP $(n=294)$ & & & 0.074 & & 0.084 \\
\hline Yes & 67 & $6.0(5.0)$ & & $36.0(4.0)$ & \\
\hline No & 227 & $6.0(4.0)$ & & $35.0(5.0)$ & \\
\hline Needle phobia on hand $(n=294)$ & & & 0.209 & & $0.019^{*}$ \\
\hline Yes & 133 & $6.0(4.0)$ & & $35.0(5.0)$ & \\
\hline No & 161 & $6.0(5.0)$ & & $36.0(5.0)$ & \\
\hline Needle phobia on back $(n=294)$ & & & 0.538 & & $0.006^{*}$ \\
\hline Yes & 252 & $6.0(4.0)$ & & $35.0(6.0)$ & \\
\hline No & 42 & $6.0(8.0)$ & & $37.0(6.0)$ & \\
\hline
\end{tabular}

* Significant at level 0.05 .

importance of LP as diagnostic method for central nervous system (CNS) infections such as meningitis and encephalitis. Therefore, educational interventions to assess the effect on the knowledge and attitude of LP should be further researched. With better knowledge and awareness, the public will become more capable to judge the risks and benefits to accept LP.19

Our study has some limitations. First, the result may only be generalizable to the study's sample population, which was selected from among the staff in a university in Malaysia. Second, the questionnaire may have only modest reliability due to the borderline Cronbach's alpha of 0.7.20 Third, we did not stratify the respondents' educational background into science and nonscience to further explore differences in knowledge and attitudes towards LP, although we did exclude medical faculties in order to minimise participation bias. In addition, due to the moderate response rate, certain subgroups in terms of ethnicity may not be statistically powered to find significant differences. Despite these limitations, this exploratory study provides useful insights into which factors affect the public's knowledge of and attitude towards LP. A more comprehensive and representative population-based study should be performed.

\section{Conclusion}

This study highlighted the problem of LP refusal and the importance of addressing this issue seriously, as it could lead to unnecessary health complications due to misdiagnosis and mistreatment. Based on our study, we found that generally the public is not adequately informed about LP, leading to unreceptive attitudes. Therefore, to mitigate this problem, we recommend that the public be given more knowledge on LP to create a better awareness of LP, particularly among those with a lower educational level.

\section{Conflict of interest}

The authors have none to declare.

\section{Acknowledgment}

The authors would like to thank Universiti Putra Malaysia for permission to conduct this study and GP-IPM/2014/9427500 grant for the financial support. The URL is http:// www.rmc.upm. edu.my/.

\section{References}

1. Hassan N. Prosedur pengambilan air tulang belakang. Utusan Online. http:// ww1.utusan.com.my/utusan/info.asp?

$\mathrm{y}=2002 \& \mathrm{dt}=0526 \&$ pub=Utusan_Malaysia\&sec=Kesihatan\&pg=kn_01.htm, Published 26 May, 2002. Accessed 29 January, 2017.

2. Boo YL, Aris MAM, Chin PW, Sulaiman WAW, Basri H, Hoo FK. Guillain-Barré syndrome complicating dengue fever: two case reports. Tzu Chi Med J. 2015; (November)10.1016/j.tcmj.2015.09.007.

3. Deng CT, Zulkifli HI, Azizi BH. Parents' views of lumbar puncture in children with febrile seizures. Med J Malays. 1994:49(3):263-268.

4. Narchi H, Ghatasheh G, Al Hassani N, Al Reyami L, Khan Q. Comparison of underlying factors behind parental refusal or consent for lumbar puncture. World J Pediatr: WJP. 2013;9(4):336-34110.1007/s12519-013-0419-z.

5. Narchi H, Ghatasheh G, Al Hassani N, Al Reyami L, Khan O. Why do some parents refuse consent for lumbar puncture on their child? A qualitative study. Hosp Pediatr. 2012;2(2):93-9810.1542/hpeds.2011-0034.

6. Ling SG, Boey CC. Lumbar puncture refusal in febrile convulsion. Singap Med J. 2000;41(10):485-488.

7. King MB, Rwegerera GM. An audit of consent practices and perceptions of lumbar puncture, Botswana inpatient setting experience. Afr J Emerg Med. 2015:5(2):66-69.

8. Hampande LM. Attitudes and Determinants of Lumbar Puncture Acceptability at Three Hospitals in Zambia. 2014 (1). 10.1007/s13398-014-0173-7.2.

9. Borhani-Haghighi A, Rezaei R, Etemadi S, Ghaem H, Shariat A. Knowledge and attitudes of Iranian patients with regard to lumbar puncture. Neurosciences. 2009; 14(4):360-363.

10. Rosamond W, Flegal K, Friday G, et al. Heart disease and stroke statistics-2007 update: a report from the American Heart Association statistics committee and stroke statistics subcommittee. Circulation. 2007;115(5):e69-e17110.1161/ CIRCULATIONAHA.106.179918. 
11. Pereira DA, da Silva Campos Costa NM, Sousa ALL, Jardim PCBV, de Oliveira Zanini CR. The effect of educational intervention on the disease knowledge of diabetes mellitus patients. Rev Lat Am Enfermagem. 2012;20(3):47848510.1590/S0104-11692012000300008.

12. Cutler DM, Lleras-Muney A. Education and health: evaluating theories and evidence. Edicat Health: Eval Theor Evid. 2006;3:710.3386/w12352.

13. Nutbeam D. Health literacy as a public health goal: a challenge for contemporary health education and communication strategies into the 21st century. Health Promot Int. 2000;15(3):259-26710.1093/heapro/15.3.259.

14. Taddio A, Ipp M, Thivakaran S, et al. Survey of the prevalence of immunization non-compliance due to needle fears in children and adults. Vaccine. 2012;30 (32):4807-481210.1016/j.vaccine.2012.05.011.

15. Association AP. Diagnostic and statistical manual of mental disorders. Washington, DC: Psychiatric Publishing; 2013.
16. Ali F, Bai P, Dungrani H, Raju M, Ustad F, Hassan I. Nature and prevalence of needle phobia among dental college patients. J Dent Res Rev. 2015;2 (3):13010.4103/2348-2915.169826.

17. Hamilton JG. Needle phobia: a neglected diagnosis. J Fam Pract. 1995;41 (2):169-175.

18. McMurtry CM, Noel M, Taddio A, et al. Interventions for individuals with high levels of needle fear: systematic review of randomized controlled trials and quasi-randomized controlled trials. Clin J Pain. 2015;31(10 Suppl):S1092310.1097/AJP.0000000000000273.

19. Ross CE, Wu C. The links between education and health. Am Soc Rev. 1995;60 (5): $71910.2307 / 2096319$

20. Boynton PM, Greenhalgh T. Selecting, designing, and developing your questionnaire. BMJ (Clin Res Ed). 2004;328(7451):1312-131510.1136/ bmj.328.7451.1312. 